\title{
Angles
}

New Perspectives on the Anglophone World

$8 \mid 2019$

Neoliberalism in the Anglophone World

\section{The Zombie Economy and the Aesthetic of Austerity}

\section{Ruth Cain and Johnna Montgomerie}

\section{Q OpenEdition}

1 Journals

\section{Electronic version}

URL: https://journals.openedition.org/angles/582

DOI: $10.4000 /$ angles.582

ISSN: 2274-2042

\section{Publisher}

Société des Anglicistes de l'Enseignement Supérieur

\section{Electronic reference}

Ruth Cain and Johnna Montgomerie, "The Zombie Economy and the Aesthetic of Austerity", Angles [Online], 8 | 2019, Online since 01 April 2019, connection on 06 June 2022. URL: http:// journals.openedition.org/angles/582 ; DOI: https://doi.org/10.4000/angles.582

This text was automatically generated on 6 June 2022.

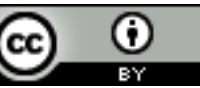

Angles est mise à disposition selon les termes de la Licence Creative Commons Attribution 4.0 International. 


\title{
The Zombie Economy and the Aesthetic of Austerity
}

\author{
Ruth Cain and Johnna Montgomerie
}

\section{Introduction}

1 A decade after the Global Financial Crisis (GFC) began, Anglo-American economies are still in the grips of protracted austerity. As many countries in the Global South have already experienced, the afterlife of neoliberal crisis is the prolonged period of 'structural adjustment' required by the entire economy to pay the costs of financial market boom and bust. The immediate demands of financial bailouts are to prevent cataclysm, quickly followed by calls for fiscal consolidation, and then protracted economic stagnation sets in, which leads to marked declines in living standards. What began in Mexico in the 1980s, and matured across multiple iterations of financial crisis, like chickens coming home to roost, austerity is the economic reality of the financialised heartland of Anglo-America and across much of Europe. Most political economy analysis focuses on debating the scale and scope of the different crises of neoliberal financialised capitalism (Lapavitsas 2009; Gamble 2014). Amidst the ongoing economic stagnation, new upheavals puncture austerity's unfolding with political polarizations. It seems neoliberalism faces a global crisis on a scale that may be hard to grasp using the well-worn analytical tools that mainstream economics and politics provide (Sassen 2014; Earle et al. 2017), not least because the mainstream methodologies were useless at analysing or understanding the eruption of political fissures that have manifested in the vote for Brexit in the UK and Donald Trump's election in the US. Indeed, the very connection between austerity and the rise of the far-right in Anglo-America is contested.

2 This article seeks another explanatory path for articulating the severity of austerity. We will focus on the theme of protracted crisis as 'undeath.' We connect the peculiar 'non-death' of neoliberalism (Crouch 2011) with forms of personal undeath, particularly through the decline experienced at the scale of the body. Whether mental 
or physical, the absolute decline of human health as a result of austerity is well documented in academic literature (Stuckler and Basu 2013; Bambra 2016; Schrecker and Bambra 2015; Mattheys et al. 2017). The extent to which austerity perpetuates a type of unacknowledged harm compliments the cultural analyses of the depredations of late neoliberalism on increasingly unsupported individuals, expected to look after themselves economically, physically and mentally, amid dwindling resources and opportunities (Fisher 2014). However, in the main, the violence and harm perpetuated by austerity is insufficiently addressed in political and cultural economy analyses of contemporary capitalism.

Drawing together both political economy and cultural studies, we advance the explanatory power of the monster as metaphor. Yet, this brings its own problems of coherence and justification. Why take the zombie and not the vampire, for example, as the undead monster with the most explanatory potential? After all, the literary vampire is part of the gothic revival under neoliberalism (Wilson 2016). The vampire is an undead monster that embodies the image of an elite aristocrat with wealth and power capable of violence without fear of repercussions. ${ }^{1}$ Marx identified capital as 'dead labour which, vampire-like, lives only by sucking living labour' (Marx 1976: 342). Marx's $19^{\text {th }}$-century solitary vampire conveys the emergent power of capital as an abstract form of domination by a remorseless monster that is not easy to identify or act against. Vampires are plausible monsters of our financialised age because of the historical association with the blood-sucking parasitic characteristics of high finance (Crosthwaite et al. 2014). Today, the vampire is the liminal figure of the psychopath, a hollow, yet driven man, who is calculating and operates in the dark shadows of society (Seltzer 1998; Taplin 2017). Vampires need not be people, but capital made person in the corporation itself, a psychopathic legal entity gobbling up human (and natural) resources in an endless drive for 'growth' (Bakan 2012; Boddy 2011). Indeed, the anonymity of the asset-stripping ' $1 \%$ ' suggests vampires with coffins stuffed with offshore assets; capital kept out of living economic circulation. The story of the vampire elite (1\%) sucking the value out of global assets to leave the rest of society anaemic because they can no longer share in the wealth created by global markets is plausible, but not the undead monster story being told in this article.

Instead, the undead monster metaphor of the zombie is used in this paper to communicate the specificity of the contemporary aesthetic of austerity. In other words, the zombie and vampire are not rivals competing for pole position as best cultural political-economy metaphor for the current epoch (McNally 2012). Rather, the vampire tells one story about the nature of elite rule under financialisation, and the zombie tells another story that highlights the grotesque embodied violence of austerity.

5 Here, we detail how finance-driven growth has become the zombie economy of austerity. In doing so, this article explores how the zombie as undead monster captures the multi-scalar manifestations of crisis under conditions of austerity in unique ways. Firstly, the zombie demonstrates how protracted crisis manifests as harm and violence to the demos, as it is manifest at the scale of the body. The vision of the undead monster with its open wounds, dishevelled clothing, decaying skin, lifeless eyes, dead brain, missing limbs, stumbling gait is collectivised into a marching horde that is disorganised but relentlessly moving forward as a cacophony of groans. It is the gruesome characteristics of the zombie that connect us to the inhumane outcomes of austerity: the numbers of humans that succumb to hunger and illness, the growing levels of 
squalor and homelessness, the gaps in social security that leave the sick without treatment and the disabled without assistance, or the armies of workers living in poverty because wages cannot sustain life. Thus, the zombie is the embodiment of austerity because it connects the corporeal manifestations of crisis to the macro- and global economy as the source of harm to the body.

This paper uses the zombie as a political economic metaphor to open up another way of communicating across disciplines the monstrous harm inflicted in Anglo-American society in the name of austerity. The zombie problematises the boundary between life and death, which in a corporeal form is an absolute binary, but in political-economic terms is currently in flux. The zombie allows us to read through the political economy of crisis to better imagine the embodiment of harm caused by austerity: the zombie as undead, unthinking, reanimated corpse relentlessly searching for another life to devour, marching in hordes whose voracious appetite cannot be satiated. The cultural capital of the zombie allows us to articulate in a new way the aesthetic of austerity. It is precisely the in-between existence of the zombie, the Dead Alive ${ }^{2}$, that allows us to think through what is dead, and what still lives, in neoliberal financialisation, a decade after the onset of the GFC (Orpana 2016).

Bringing together the political economy understanding of austerity with the cultural studies readings of the zombie, we explore the afterlife of the GFC as it is embodied as a monstrous violence perpetuated on society. Austerity is not just a public policy platform that can be assessed in terms of policy successes and failures, costs and benefits. Austerity is a (necro-)political force transforming the role of the state in markets and society. The harm and violence inflicted by austerity is embodied in the zombie, the undead monster seeking to devour the demos. The first section explains how TINA ('There Is No Alternative') acts as zombie overlord, providing the battle plans for the march of austerity; yet, TINA remains ever vulnerable to alternative politicaleconomic imaginaries that want neoliberalism to end. In the second section, the zombie is the mass violence of undeath; the visceral way austerity inflicts harm is understood in terms of the experiential and emotive. The mythical zombie monster evokes the tone and substance of the transformations induced by austerity, the harm caused by cuts to social security, and the everyday subtle violence of declining living standards. Finally, the paper concludes by making the connection between the aesthetic of austerity as the zombie and the rise of right-wing proto-fascism in Anglo-America.

\section{TINA - the Neoliberal Zombie Overlord}

8 The continuity between neoliberalism and austerity is most obvious in the 'There Is No Alternative' (TINA) ethos, which is used for every manner of justification, but in this case is used to demand that austerity must follow a financial crisis. Austerity articulates the current phase of economic fatalism; with financial crisis comes bailouts for some, and austerity for the rest (Montgomerie 2016). The permeation of popular and academic culture with zombie metaphors is a product of a volatile and intensifying hyper-neoliberal economic climate (Randell-Moon et al. 2013: 55). According to various zombie mythologies, zombies may be summoned into existence by a zombie-master: a witch doctor or other person or entity with demonic power. Thus, zombies evoke the 'necropolitics' of increasingly authoritarian Western states which deal out routine violence both to citizens of foreign countries in acts of war, and to their own domestic 
'underclass' (Mbembe 2003). Necromancy, or the magical control over the dead, offers a different way of understanding the sociology of power under conditions of austerity.

Capital has long been theorised as a fundamentally 'undead' force, as the worker is alienated from the products of his labour and increasingly from an over-commodified culture itself: the most Gothic description of capital is also the most accurate. Capital is an abstract parasite, an insatiable vampire and zombie-maker; but the living flesh it converts into dead labour is ours, and the zombies it makes are us (Fisher 2009: 15). Literary historian E.J. Clery (1995) writes of the haunted Gothic fiction of late $18^{\text {th }}$ century England, a troubled land where industrialisation was restructuring the nature of work at a ferocious pace, consuming human flesh to solidify its advance. Reminiscent of the accelerated neoliberal techno-capitalism of the early $21^{\text {st }}$ century, in these horrific industrial tales "the living dead join a host of other spectral figures - vampires and other monsters [...] who have been vectors of an affective engagement with the visceral implications of the factory, the plantation, the market, the mine" (Clery 1995: 9). Zombies are the stuff of 'estranged recognition' (Clery 1995: 114).

The zombie offers a deeply troubling recognition of the "invisible predations that seem to congeal beneath the banal surfaces of new forms of wealth" (Comaroff and Comaroff 2002: 795). Zombies tell us of the colonial legacy of capitalism as they roamed the plantations as slaves summoned into being by acquisitive witchcraft. ${ }^{3}$ In contemporary times, zombies populate the blasted landscapes of dystopian literature, film and television (Romero 1978). Their living death is the death of state-backed systems of social reproduction, and of the individual forced to emulate an empty entrepreneurial ethic of constant expansion and consumption. "In their iconography of forced migration and wandering exile [...] the living dead comment on the disruption of an economy in which productive energies were once visibly invested in the reproduction of a situated order of domestic and communal relations" (Comaroff and Comaroff 2002: 796). On a broader metaphorical level, the zombie is our future in a post-apocalyptic nightmare where global warming and/or accelerating political instability have created a world fit only for the already-dead.

11 From a cultural perspective, zombies represent the abject aspect of a broader and previously utopian cultural move to 'post-humanity' (Lauro and Embry 2008); they are what is left when humanity has completely or almost wiped itself out. They embody the blind neoliberal drive to keep consuming, to reproduce and grow exponentially regardless of environmental, social and personal destruction. Thus, we often see the cinematic or televisual zombie staggering on as bits of its body fall off or are amputated, until perhaps a still-crawling torso or disembodied head continues to grope for, or gnash at, its prey. Since the zombie consumes all living matter in its path, and creates only endless copies of itself, it can only usher in a post-apocalyptic state. Necromancy also predicts the inevitable future caused by raising the dead. Thus, an effective metaphor "not only for how capitalism transforms its subjects but also for its relentless and devastating virologic march across the globe" (Canavan 2010: 432) has only one reasonable outcome - extinction. The zombie thus represents the endless inhuman 'drive' of capitalism, which has a sinister resonance with the malfunctioning machinery of financial capitalism itself (Dean 2013).

For the zombie to emerge in times of crises suggests the fear generated by shifts in the unfolding of capitalism. Thus, the zombie articulates the alienation felt by those whose increase in labour is accompanied by a decrease in control and autonomy over their 
own lives (Randell-Moon et al. 2013: 59). This same theme of undeath is echoed by the post-GFC analysis of Ben Fine that notes neoliberal financial capitalism "is alive but it is not well because it is also dead" (Fine 2008: 2), his description of the creation of 'zombieconomics' is worth quoting at length:

There are two reasons why the mainstream economics in the current phase of neoliberalism is zombie-like. First, it is both dead and alive at the same time, undead as popular culture would have it. That it prevails within its own disciplinary boundaries with little or no contest and with scant respect for alternatives is more or less uncontroversial [...]. [Zombie economists] are totally insensitive to the considerations of the living but merely respond to an inner inescapable logic and, occasionally, perpetrate mysterious jerking movements of their own. (Fine 2008:1)

In the immediate moment of crisis, speaking in 2008, Fine evokes the unthinking and unfeeling monster that the discipline of Economics has unleashed on humanity. In this account, the zombie is not so much brainless as without mercy or reflexivity. Fine is not alone; the GFC immediately provoked many metaphors of living death. "When our computers are compromised by hackers or viruses, they become zombie computers, and when our financial institutions fail, it is because they are zombie banks" (Canavan 2010: 432). Indeed, it was the Japanese financial crisis in the 1990s that gave rise to the popular term 'zombie banks' as a way of explaining how financial institutions can operate when 'functionally insolvent' (or, with more liabilities than assets or cash) because state-funded bailouts and central bank administered Quantitative Easing (QE) reanimates a failed bank, without making it solvent again. Following the GFC, multiple scholarly analyses described a global 'zombie economy', and gothic and zombie metaphors for the post-GFC world began to proliferate in left-wing political, economic and cultural analyses (Peck 2010; Fisher 2013; Giroux 2010; Wilson 2016; McNally 2012; Kuhling 2017).

Indeed, Colin Crouch's (2011) analysis of the 'strange non-death of neoliberalism' juxtaposes the comparatively rapid historical death of liberal England in the early $19^{\text {th }}$ century - as argued by Dangerfield (2017) - with the contemporary resilience of neoliberalism to emerge from financial collapse "more politically powerful than ever" (Crouch 2011: x). In the same time period, descriptions and confessions of personal feelings of 'living death' (by which we mean to indicate depression and other uncategorisable forms of mental suffering and mental health decline) among relatively affluent inhabitants of Anglo-America have increased across all age-categories (Knapp 2012). Austerity is materially affecting people's brains, as the mental and emotional strain of protracted economic stagnation and political polarisation creates states of depression in both people and the political economy. It is 'The zombie named TINA' (Casey 2011) acting as the personification of Thatcher's famous dictate that 'there is no alternative' that forecloses any way out of depression, stagnation and economic fatalism. It was TINA that brought the death of post-war Keynesianism; this threat now looms large in the everyday life of austerity. For Casey, TINA is a zombie overlord, the principle of economic undeath personified; for us, TINA the zombie overlord captures the aesthetic of austerity in a very meaningful way because it connects the death of economic ideas with the living death of the economy itself.

Zombie as the living death of economic ideas is articulated in John Quiggin's Zombie Economics (2012) which details how long-dead economic ideas about the existence of 'efficient markets' or 'dynamic stochastic' models of general equilibrium (DSGE) continue to be used within academic economics, economic policy and governance, 
despite the widely-acknowledged reality that economic ideas (concepts, models and theories) do not work well as tools for analysing empirical reality. In the GFC and the calls for (yet more) bailouts of the financial sector, we can see the same dead economic ideas "clawing their way up through the soft earth" (Quiggin 2012: 8) to once more dominate policy-making. The zombie epitomises a relentless desire implicit in the systems and logic of neoliberal financial capitalism, to remain undead rather than accept the finality of 'real' death.

Thus, the aesthetic of austerity is expressed in the agenda of economics enacted by political elites seeking to sustain the system that continues to benefit them. TINA acts as zombie overlord in which the neoliberal political economy 'wins' by doing wrong and causing harm, by being 'too big to fail.' As Jamie Peck (2010) articulates, neoliberal capitalism has "become mired in the unending challenge of managing its own contradictions, together with the social and economic fallout from previous deregulations and harmful interventions. It fails, but it tends to fail forwards" (Peck, 2018: 106). The pattern of sustained economic crisis does not discredit neoliberalism; on the contrary, crisis emboldens neoliberalism to advance with ever more deregulation and wrong-headed economic and political interventions. The zombie is 'Dead but dominant':

[T]he brain has apparently long since ceased functioning, but the limbs are still moving, and many of the defensive reflexes seem to be working too. The living dead of the free-market revolution continue to walk the earth, though with each resurrection their decidedly uncoordinated gait becomes even more erratic. (Peck 2010: 109)

Thus, dead ideas continue to rule the global economy as austerity in the Anglosphere demonstrates. Fact and truth do not diminish the intellectual credibility of austerity as an economic agenda because of the political force that sustains it.

\section{Austerity and the Violence of Undeath}

18 In zombies we recognise human form without the vulnerability of the corporeal or agency bestowed by life. The zombie is thus a resonant 'crisis metaphor' for the increasingly dystopian aesthetic of austerity. What is rendered dead by austerity is the political credibility of the post-war welfare state; what we see today is a reanimated monster no longer able to provide collective provision of social security. What stays alive in the zombie economy is the boom-and-bust cycle, debt-led economic growth, and globalised financialization. As such, the zombie can also help us to understand how crisis at the scale of the body in terms of death and death-like states connects to the macroeconomy and global economy. Austerity produces forms of undeath; a violence or harm that is not absolute or obvious, contingent and subtle at the individual level, but obviously visible on the aggregate.

The power of austerity is first meted out by way of the economic ideas that justify it, the political project that sustains austerity and the harm austerity perpetuates on people's lives, which is embodied in the gruesomeness in the unthinking, remorseless zombie seeking to feast on anything it its path. Thus, the necromancing power of neoliberalism becomes evident in the persistence of discredited neoliberal ideas of Friedrich A. Hayek, Milton Friedman and Ayn Rand as they are wielded by the political elite. This resembles necromancy inasmuch as dead economists and political 
philosophers are reanimated and deployed to destroy alternative futures. It does not matter that the economic and political ideas of the first generation of neoliberals have spectacularly backfired, indeed imploded; they cannot die as long as political choice continues to reanimate them. Necromancy explains what problematising the practices of scientific knowledge cannot, namely the almost mythical power of political elites to use dead ideas. If something is disproven, inasmuch as it does not exist in evidence, it is not real and, therefore, should not be used to inform political economic analysis or public policy. This is exemplified by the Reinhart and Rogoff (2011) controversy, in which rigorous economic analysis of the connection between cutting government debt and increasing economic growth was proved to be methodologically and statistically dubious (Coy 2013), yet persists as the dominant policy paradigm in Anglo-America and Europe. For academics, especially those committed to both enlightenment principles and the scientific method, the continued existence of the discredited idea of austerity is 'dangerous' (Blyth 2013) because it contradicts dominant belief systems around what political economy is and how it is used. For instance, austerity continues to live on in political, economic and public policy circles despite overwhelming evidence that it will not foster a 'recovery' from crisis and perpetuates harm to people who did not cause the crisis in the first place.

Taking zombie form problematises the boundary between life and death itself, which in a corporeal form is (supposedly) an absolute binary, but in political and economic terms is fluid, and is in particularly obvious flux in these 'end times' of neoliberalism (Peck 2013). The zombie metaphor provides a means of reflecting on the political tumult and personal harm caused by present-day austerity as it connects what is normally threatened as three separate spheres of the economy, politics, and the body. Economic and political living death manifests in the body as the many forms of physical and mental illness, decline and necrosis that accompany rising inequality and savage cuts to social security in the name of austerity (Schrecker and Bambra 2015). The sense of hopelessness arising from the apparent final triumph of neoliberalism over its alternatives links individual mental depression to global economic depression. Thus, rising unemployment and underemployment, combined with welfare conditionality, acts to limit the opportunities for meaningful collective community and sustaining of life.

Understanding austerity as the latest articulation of neoliberalism makes room for understanding how political and economic aesthetics change, sometimes very rapidly. Both economic and non-economic analyses of austerity apply a reductionism that endows zombie economics with life but with little content, both in terms of analytical elements and understanding of the necessities of human life. Zombie economics is dead in that it is based upon an unquestioned methodological individualism and technical apparatus of the narrowest type; it is ignorant of its own history, of its methodology and of alternatives (Cooper 2012).

Exploring the monstrous characteristics of austerity in the Anglosphere seeks to examine the inner workings of living death at the scale of the body and macroeconomy. Living death can be seen in mental ill-health. It should be noted, however, that largescale studies of the effects of relative deprivation and inequality (Wilkinson and Pickett 2010) demonstrate that mental and physical suffering, as well as other pathologies such as addiction and decreasing trust in others, are connected responses to late-neoliberal social and economic policies. Encroaching death or restricted life is another, and thus 
we look to the explanatory potential of the undeath metaphor to understand the contemporary political-economic and physical/mental pathologies of Anglo-America.

In the period immediately following the financial crisis, individual bankers were temporarily portrayed as pathological 'gamblers', and the 'boom-and-bust' capitalist system as a mass-manifestation of pathological mania (Dean 2013). From the bipolar symptomatology of market 'boom-and-bust', to the manias and panics of market crashes, to Great Depression, economic malaise or financial melancholia, the psychological dynamics of economics tend to only be articulated as explanations for the onset of the crisis, not the lived reality of austerity (Davies et al. 2015). Notably, market movements and their makers were pathologised by most commentators only after the GFC; when the market continued to boom, it was simply behaving gratifyingly, rewarding appropriate investment.

At the same time, the 'zombie bankers' who marched and danced during the Occupy London and Wall Street protests (Nyong'o 2012: figs 1-3) expressed the appetite of austerity with signs ordering onlookers to 'feed me your hospitals, feed me your schools.' Like the zombie, the banker often preys in herd formation. The sub-prime borrower, conjured as a person of colour who wanted to buy a home he/she could not afford, is an image that lasts in the collective memory far longer than the gambling 'banksters' (Giroux 2012). Thus, the harm experienced by sub-prime borrowers, creditdefaulters and everyday debtors in Anglo-America was deserved because they 'lived beyond their means' for far too long (Montgomerie 2010; Walker 2012). The power of guilt and collective moral responsibility for austerity was critically underrated by postcrash commentators who believed that the GFC would be followed by a complete reformation of neoliberal financial and political structures (Konings 2016). Instead, as Stanley (2014) also notes, collective values of thrift, personal responsibility and resilience were emphasised, and quickly gained traction in Anglo-America.

\section{The Monstrous Embodiment of Austerity}

Traditional political-economy understandings of crisis are usefully refracted through the lens of affect when we use the zombie metaphor to examine the connection between psycho-social and socio-economic harm and the everyday life of austerity. The 'living dead' subject appears in more complex guises than ever, at a time of widespread and documented depression and other mental health issues (Knapp 2012; Pokonorwski 2016). Living death thus becomes an existence and culture without affect or future, a non-life endured particularly by the young, for whom previously-normal economic aspirations such as a family home have become remote. Mark Fisher sums up the eerie disappearance of a better or different future in the coherent epoch: "this place is nowhere, and it's forever" (2014: 2). Austerity brings a new theoretical focus on depression and states of living death in the lives of the harassed citizens of late neoliberalism (Cain 2018). In its dissociation, numbness, persistence and lack of feeling, the zombie very effectively encodes the complexities and contours of a very contemporary epidemic of economic and affective living-deadness (Fisher 2009). Mental illness, particularly depression and anxiety, is increasingly prevalent and articulates a specific aesthetic of contemporary Anglo-American variant of austerity. Here, the falsehood of 'free choice' demotivates and depoliticises, forcing individuals 
endlessly back upon diminishing resources of energy and capital. Thus, depression, anxiety and narcissism are manifest in the ethos of austerity.

Scholars are increasingly making thematic and material connections between the social and economic causes of the measurable decline in physical and mental health in postausterity states such as the UK. Connecting austerity, health-service cutbacks and the resulting biological disenfranchisement, Matthew Sparke claims that "in relation to austerity across Europe after the 2008 financial crisis [...], the embodied experience of austerity repeatedly leads from market discipline to widespread morbidity and mortality" (2017: 288). The relentless march of spiralling inequality, withdrawal of basic state support, unemployment and precarious work is making people physically and mentally sick. Sparke elaborates: "efforts to restore business confidence and promote pro-market growth by cutting the costs of public services tend also to make poorer populations vulnerable to disease, disability and premature death" (Sparke 2017: 289). Adapting the acronym for structural adjustment programs (SAPs), this involves what Steve Gloyd (2004: 289) calls "SAPping the poor", a process through which already-overburdened health systems for poor populations are sapped of all resources. The zombie is an avatar of the horrors of austerity capitalism, where homo economicus is transformed from a rational-acting profit-maximiser who collectively benefits through the market mechanism, to a monster immune to the pain and suffering of others, relentlessly searching for fresh brains to devour.

Zombies, in their expendable de-individuated horde of groans (Shaviro 2002), are most feared because they destroy the future, the promise of life not yet lived. Here the aesthetic connection between austerity and the precarious millennial generation is most chilling. Today's young people might be figured as the ultimate contemporary victim/avatar of undeath, depleted youth without vitality because they are denied the promise of a better future. These disappointed youth are trapped by student debt or trapped by the empty 'depressive hedonia' of consumer capitalism, which is all there is to offer the heavily-leveraged young (Fisher 2009: 21-22). As David McNally (2012) suggests, the undead represent the agents as well as the victims of rapacious capitalism. Zombies represent the despair of living death in a physically- and emotionally-deadening era. Resistance is more likely to be a process of convalescence than a dramatic act of refusal (Cain 2018). Giving up is reasonable when faced with a system too complex to understand, capitulation or abdication of political responsibility is appealing to those seeking to protect themselves from the violence of austerity. As TINA pushes on, more debt feeds the indebted to make them ripe for securitisation, just as depleted debtors are easy prey for zombie banks.

Yet, there are always alternatives to the economics of living death; we are simply discouraged from contemplating them, until such a time that austerity is accepted as eternal and deserved. No solutions are being offered to the living-deadness of social and economic life other than to simply pull up one's socks, take responsibility and get on with it. As the zombie devours the human body, making a copy of itself, it destroys identity and the collective future of humanity. Instead, the zombie creates a proliferative living death as the horde invades everything around it. 


\section{Conclusion: Fight the Dead, Fear the Living}

30 This article sought to bring together the cultural political-economy reading of austerity with the cultural-studies readings of the zombie, to explore the afterlife of the GFC as it is embodied as the undead monster perpetuating violence on society. We conclude by considering how the zombie economy as the aesthetic of austerity creates new ways of understanding the emergence of far-right, potentially proto-fascist, politics festering within Anglo-America.

31 The term 'fight the dead, fear the living' refers to Robert Kirkman's (2010) The Walking Dead graphic novel series, in which the reader encounters the tensions and ambiguities of living in a post-apocalyptic world destroyed by zombies. We use it here to evoke the tensions of political resistance that must simultaneously fight the undead economic ideas of neoliberalism that continue to dominate the political agenda despite the obvious social and economic decay it fosters, and fight the ideas of far-right populism that continue to gain traction. As the necromancy of neoliberalism's non-death enslaves the future by foreclosing alternatives, as austerity inflicts harm on evergrowing segments of the population, a violence is building up in the Anglosphere. At times the anger is directed at elites, the $1 \%$; at other times, anger and rage are focused on the identities and bodies of women, migrants, Muslims or just dark-skinned people. At the same time, austerity imposes cuts on social security and services to the elderly, the sick, the disabled, children and anyone on a low income. The zombie metaphor allows us to consider how the aesthetic of austerity shapes and influences the rise of far-right politics and proto-fascism in Anglo-America.

The zombie metaphor forces us to consider the degree to which the aesthetic of austerity is embodied as various states of decline and necrosis, which is manifest as the deep structural crisis indicative of the terminal decline of financialised capitalism. Neoliberalism is in a state of permeant crisis; this political economic condition is best described by Antonio Gramsci as the 'interregnum:' “The crisis consists precisely in the fact that the old are dying and the new cannot be born; in this interregnum a great variety of morbid symptoms appear" (Gramsci 1971: 77). It is these 'morbid symptoms' that are manifest in the zombie economy, as austerity produces different bodily states of decline and necrosis. The toxicity of economic and embodied/subjective living death should be seen not only as a property of the victims and sufferers of austerity; the elites contribute - as the zombie overlords - to the values and aesthetic of austerity by continuing to profit from relentless consumption, debt culture and the degradation of living conditions rampant across Anglo-America. The undead zombie horde is relentlessly marching ever forward, with no capacity to improve their condition. We see the rage of this condition expressed in the case of the Brexit 'majority' who want to 'take back control' or the Trump-voting 'masses' that want to 'make America great again', each expressing an ethos of re-animating a long-dead past.

The connection between austerity and far-right populism is articulated as the harm perpetuated on the marginalised communities 'left behind' by the zombie economy. The angry white working-class communities, whether in the American Rust Belt or post-industrial Northern Britain, exist as states of political economic undeath. They exist without economic vitality, sustained by state-funded life-support, without a future. Goodwin and Heath (2016) and Inglehart and Norris (2016) identify Brexit and Trump voters with the 'left behind' or 'have-nots' of globalisation, resentful of their 
loss of opportunity and privilege. These forgotten places and the people that inhabit them have no capacity to change their condition, these communities direct and mobilise their anger at 'immigrants' or 'foreigners' or the immoral Welfare Queens and Skivers (Hall et al. 2017). "Older, working-class, white voters, citizens with few qualifications, who live on low incomes and lack the skills that are required to adapt and prosper amid the modern, post-industrial economy" (Goodwin and Heath 2016: 404). The strangely numb acceptance of austerity and inequality among these 'leftbehind' populations of voters, who include many people who are themselves relying on social security, is indicative of the power of TINA to annihilate alternatives (Forkert 2014).

34 Another connection with the zombie economy aesthetic of austerity is the relative states of undeath represented in the ageing population supporting the far-right in both the Republican Party and the Brexit campaign. The theme of near-death is expressed in the decrepitude and myopia of the over-60 voters who delivered both Trump and Brexit narrow victories (Hitchings-Hales 2016). Mapping the various states of bodily decline with the political-economic necrosis of the US and the UK reveals the very specific populations that swung support behind the far-right (Monnat and Brown 2017; Bor 2017). In the UK, health geographers have recently warned that 'life expectancy in England and Wales [since 1945] has now slowed markedly, and at older ages may even be reversing' (Hiam et al 2018). Post-industrial areas of Britain, especially the North East of the UK and South Wales, have seen the parallel outcomes of restricted lifespan because of austerity and voting Brexit, particularly among white voters (Dorling 2016). Suicide rates and acts of intentional death are also on the rise in these left-behind communities; in the UK, these rates are especially elevated for middle-aged men (ONS 2017a). Among young people who have a weaker generational attachment to ideas of nationalism and racial identity, as Fisher notes (2014), the awareness of 'no future' appears to lead to the 'depressive hedonic' state of apathy brought on by continual attempts to relieve anxiety. Addiction, suicide and earlier death among younger people is also rising in the areas where overall health outcomes and age of death are in the most precipitous decline (ONS 2017b, 2017c).

When we consider the ways in which the harm and violence inflicted by austerity is expressed as bodily decay and undeath, and how the violence of undeath connects in a visceral, experiential and emotive way to how austerity inflicts harm, the connection between austerity and far-right populism and proto-fascism is that they share an aesthetic (Rawnsley 2018). The mythical zombie monster evokes the tone and substance of the transformations induced by austerity, the harm caused by cuts to social security and globalisation, and the subtle but persistent violence of declining living standards amplified through the anger and distrust of voters supporting the far-right, seeking to resist the undeath of financialised capitalism by fighting the living people they consider the enemy of national capitalist interests. 


\section{BIBLIOGRAPHY}

Bambra, Clare. Health Divides: Where you live can kill you. Bristol: Policy Press, 2016.

Bakan, Joel. The Corporation: The pathological pursuit of profit and power. London: Constable, 2012.

Blyth, Mark. Austerity: The History of a Dangerous Idea. Oxford: Oxford UP, 2013.

Boddy, Clive. Corporate Psychopaths: Organizational Destroyers. Basingstoke: Palgrave Macmillan, 2011.

Bor, Jacob. "Diverging life expectancies and voting patterns in the 2016 US presidential election." American Journal of Public Health 107(10) 2017: 1560-1562.

Cain, Ruth. "How neoliberalism is damaging your mental health." The Conversation, 30 January 2018. https://theconversation.com/how-neoliberalism-is-damaging-your-mental-health-90565

Canavan, Gerry. “'We are the walking dead': race, time and survival in zombie narrative." Extrapolation 51(3) 2010: 431-53.

Casey, Terrance. "Capitalism, crisis, and a zombie Named TINA", in Terrance Casey (ed.). The Legacy of the Crash: How the financial crisis changed America and Britain. Basingstoke: Palgrave, 2011: 38-59.

Cooper, Christine. "Accounting for the fictitious: living death by mainstream economics." Paper presented at Interdisciplinary Perspectives On Accounting Conference, University of Strathclyde, 11 July 2012. https://strathprints.strath.ac.uk/42594/

Coy, Peter. "FAQ: Reinhart, Rogoff, and the excel error that changed history." 18 April 2013. http://www.bloomberg.com/news/articles/2013-04-18/faq-reinhart-rogoff-and-the-excel-errorthat-changed-history

Crosthwaite, Paul, Peter Knight and Nicky Marsh. Show Me the Money: The image of finance, 1700 to the present. Manchester: Manchester UP, 2014.

Crouch, Colin. The Strange Non-death of Neo-liberalism. Cambridge: Polity, 2011.

Clery, E.J. The Rise of Supernatural Fiction, 1762-1800. Cambridge: Cambridge UP, 1995.

Comaroff, Jean, and John Comaroff. “Alien-nation: zombies, immigrants, and millennial capitalism." The South Atlantic Quarterly 101 (4) 2002: 779-805.

Dangerfield, George. The Strange Death of Liberal England: 1910-1914. London: Routledge, 2017.

Davies, William, Johnna Montgomerie and Sara Wallin. Financial Melancholia: Mental health and indebtedness. London: Political Economy Research Centre, 2015.

Dean, Jodi. "Complexity as capture: Neoliberalism and the loop of the drive." New Formations (80-81) 2013: 138-151.

Dorling, Danny. "Public health was declining rapidly before the Brexit vote." Public Sector Focus, July/August 2016: 20-2.

Earle, Jonah, Cahal Moran and Zach Ward-Perkins. The Econocracy: On the perils of leaving economics to the experts. Harmondsworth: Penguin. 2017.

Fine, Ben. "Zombieconomics: The Living Death of the Dismal Science in the Age of NeoLiberalism.” Paper for ESRC Neoliberalism Seminar, 1 April 2008. https://eprints.soas.ac.uk/ 5621/1/Zombiekean.pdf 
Fisher, Mark. Capitalist Realism: Is there no alternative? London: Zed, 2009.

Fisher, Mark. "How to kill a zombie: strategizing the end of neoliberalism." Open Democracy, 18 July 2013. https://www.opendemocracy.net/mark-fisher/how-to-kill-zombie-strategizing-endof-neoliberalism

Fisher, Mark. Ghosts of my life: Writings on depression, hauntology and lost futures. London: John Hunt Publishing, 2014.

Forkert, Kirsten. "The new moralism: austerity, silencing and debt morality." Soundings 56 (2014): 41-53.

Gamble, Andrew. Crisis Without End? The Unravelling of Western Prosperity. Basingstoke: Palgrave Macmillan, 2014.

Giroux, Henry. Zombie Politics and Culture in the Age of Casino Capitalism. New York: Peter Lang, 2010.

Gloyd, Steve. "SAPping the Poor: The impact of Structural Adjustment Programs", in Meredith Fort, Mary Anne Mercer and Oscar Gish (eds). Sickness and Wealth: The corporate assault on global health, Cambridge: South End Press, 2004: 43-54.

Goodwin, Matthew and Oliver Heath. "Brexit vote explained: poverty, low skills and lack of opportunities.” Joseph Rowntree Foundation, 31 August 2016. https://www.jrf.org.uk/report/ brexit-vote-explained-poverty-low-skills-and-lack-opportunities

Gramsci, Antonio. Selections From the Prison Notebooks of Antonio Gramsci. New York: International Publishers, 1972.

Hall, Steve, Simon Winlow and Craig Ancrum. Criminal Identities and Consumer Culture. Cullompton: Willan, 2008.

Hiam, Lucinda, Dominic Harrison, Martin McKee, and Danny Dorling. "Why is life expectancy in England and Wales 'stalling?" Journal Epidemiology and Community Health 72 (5) 2018: 404-8.

Hitchings-Hales, James. “Age Gap: How the old defied the young on Brexit and Trump." Global Citizen, 17 November 2016. https://www.globalcitizen.org/en/content/age-gap-voters-youngold-brexit-trump-demographic/

Inglehart, Ronald and Pippa Norris. "Trump, Brexit, and the rise of populism: Economic havenots and cultural backlash.” Harvard Faculty Research Working Paper Series, 2016. https:// faculty.uml.edu/sgallagher/Trump_Populism_Norris.pdf,

Kirkman, Robert. The Walking Dead. Orange, CA: Image Comics, 2010.

Knapp, Martin. "Mental health in an age of austerity." Evidence-Based Mental Health 15 (2012): 545.

Konings, Martijn. “The spirit of austerity.” Journal of Cultural Economy 9 (1) 2016: 86-100.

Kuhling, Carmen Leah. "Zombie banks, zombie politics and the 'Walking Zombie Movement': Liminality and the post-crisis Irish imaginary." European Journal of Cultural Studies 20 (4) 2017: 397-412.

Lapavitsas, Costas. "Financialised capitalism: Crisis and financial expropriation." Historical Materialism 17 (2) 2009: 114-48.

Lauro, Sarah Juliet and Karen Embry. "A zombie manifesto: the nonhuman condition in the era of advanced capitalism." boundary 2, 35(1) 2008: 85-128. 
Mattheys, Kate, Jonathan Warren, and Clare Bambra. "'Treading in sand': A qualitative study of the impact of austerity on inequalities in mental health." Social Policy \& Administration 52 (7) 2017: 1275-89.

Marx, Karl. Capital: A critique of political economy. Volume 1. New York: Random House, 1976.

Mbembe, Achille. “Necropolitics.” Public Culture 15 (1) 2003: 11-40.

McNally, David. Monsters of the Market: Zombies, vampires and global capitalism. London: Haymarket, 2012.

Monnat, Shannon M. and David L. Brown. "More than a rural revolt: Landscapes of despair and the 2016 Presidential election.” .Journal of Rural Studies (55) 2017: 227-36.

Montgomerie, Johnna. "Neoliberalism and the making of subprime borrowers." In Martijn Konings (ed.). The Great Credit Crash. London: Verso, 2010: 103-18.

Montgomerie, Johnna. "Austerity and the household: The politics of economic storytelling." British Politics 11 (4) 2016: 418-37.

Nyong'o, Tawia. “The scene of occupation.” TDR: The Drama Review 56 (4) 2012: 136-149.

Office for National Statistics. "Statistical Bulletin: Suicides in the UK: 2016 registrations." London: ONS, 2017a. https://www.ons.gov.uk/peoplepopulationandcommunity/ birthsdeathsandmarriages/deaths/bulletins/suicidesintheunitedkingdom/2016registrations

Office for National Statistics. "Deaths related to drug poisoning in England and Wales: 2016 registrations." London: ONS, 2017b. https://www.ons.gov.uk/peoplepopulationandcommunity/ birthsdeathsandmarriages/deaths/bulletins/deathsrelatedtodrugpoisoninginenglandandwales/ 2016registrations

Office for National Statistics. "Alcohol-specific deaths in the UK" main dataset." London: ONS, 2017c. https://www.ons.gov.uk/peoplepopulationandcommunity/healthandsocialcare/ causesofdeath/datasets/alcoholspecificdeathsintheukmaindataset Orpana, Simon. "Spooks of biopower: the uncanny carnivalesque of zombie walks." Topia (25) 2011: 153-176.

Peck, Jamie. “Zombie neoliberalism and the ambidextrous state”. Theoretical Criminology 14 (1) 2010: 104-10.

Peck, Jamie. “Austere reason, or the eschatology of neoliberalism's End Times.” Comparative European Politics (11) 2013: 713-21.

Pokonorwski, Steven. "Vulnerable life: zombies, global biopolitics, and the reproduction of structural violence.” Humanities (5) 2016: 71-93.

Randell-Moon, Holly Sue Saltmarsh and Wendy Sutherland-Smith. "The living dead and the dead living: contagion and complicity in contemporary universities." In Andrew Whelan, Ruth Walker and Christopher Moore (ed.). Zombies in the Academy: Living death in higher education. Bristol, Intellect Books, 2013: 53-65.

Rawnsley, Andrew. "A zombie Prime Minister has proved remarkably difficult to finish off." Guardian, 3 June 2018. https://www.theguardian.com/commentisfree/2018/jun/03/theresa-mayzombie-prime-minister-difficult-to-finish-off

Reinhart, Carmen M. and Kenneth S. Rogoff. This Time Is Different: Eight centuries of financial folly. Princeton: Princeton UP, 2011.

Romero, George A. Dawn of the Dead. Italy, USA: Laurel Group, 1978. 
Sassen, Saskia. Expulsions: Brutality and Complexity in the Global Economy. Cambridge, MA: Harvard UP, 2014.

Schrecker, Ted, and Clare Bambra. How Politics Makes Us Sick: Neoliberal epidemics. Basingstoke: Palgrave, 2015.

Seltzer, Mark. Serial Killers: Death and Life in America's Wound Culture. New York: Routledge, 1998. Shaviro, Steve. "Capitalist Monsters." Historical Materialism 10(4) 2002: 281-90.

Sparke, Matthew. "Austerity and the embodiment of neoliberalism as ill-health: Towards a theory of biological sub-citizenship.” Social Science and Medicine 187 2017: 287-295.

Stanley, Liam. “'We're reaping what we sowed': everyday crisis narratives and acquiescence to the age of austerity." New Political Economy 19(6) 2014: 895-917.

Stuckler, David, and Sanjay Basu. The Body Economic: Why austerity kills. New York: Basic Books, 2013.

Thomson, Rachel M. and Srinivasa Vittal Katikireddi. "Mental health and the jilted generation: Using age-period-cohort analysis to assess differential trends in young people's mental health following the Great Recession and austerity in England". Social Science \& Medicine (214) 2018: 133-143.

Quiggin, John. Zombie economics: how dead ideas still walk among us. Princeton, NJ: Princeton UP, 2012.

Walker, Carl. "Personal debt, cognitive delinquency and techniques of governmentality: Neoliberal constructions of financial inadequacy in the UK." Journal of Community and Applied Social Psychology (22) 2012: 533-8.

Wilkinson, Richard and Kate Pickett. The Spirit Level: Why equality is better for everyone. Harmondsworth: Penguin, 2010.

Wilson, Japhy. "Neoliberal gothic." In Simon Springer, Kean Birch and Julie MacLeavy (eds). The Handbook of Neoliberalism. London: Routledge, 2016: 592-602.

Winlow, Simon, Steve Hall and James Treadwell. The Rise of the Right: English nationalism and the transformation of working-class politics. Bristol: Policy Press, 2017.

\section{NOTES}

1. The short novel by John William Polidori (1819), The Vampyre: A tale, was inspired by the poet Lord Byron to whom Polidori acted as personal physician; in turn, Polidori's book influenced Bram Stoker's novel Dracula (1897).

2. Dead Alive is the US title of the cult zombie horror comedy Braindead (1992) directed by Peter Jackson.

3. Jean and John Comaroff (2002) describe the zombie as a personification of labourers' fears of abduction into slavery and reduction to 'ghost labor' in late $19^{\text {th }}$ and early $20^{\text {th }}$ century South Africa. Such motifs, they argue, were coincident with new structures of colonial labour and social organisation. 


\section{ABSTRACTS}

This article explores the present-day zombie economy as the embodiment of the aesthetic of austerity in Anglo-America. It uses the zombie monster metaphor to capture the multi-scalar manifestations of crisis under conditions of enduring austerity in unique ways. The theme of undeath, or living death, connects 'dead' economic ideas that are reanimated through the zombie economy to the logic of 'there is no alternative' (TINA). Moreover, the zombie monster permits a visceral connection between the harm inflicted on people's physical and mental health and the underlying set of values perpetuated by austerity. It is the crisis at the scale of the body that manifests as the zombie macroeconomy of austerity. The contribution of this paper is that it articulates the aesthetic of austerity as the troubled boundary between what is alive and what is dead, which in a corporeal form is an absolute binary, but in political-economic terms is currently in flux.

Cet article s'attache à étudier l'économie zombie contemporaine, en tant qu'incarnation de l'esthétique de l'austérité dans le monde anglo-américain. Il recourt à la métaphore du monstre zombie pour saisir de manière originale les manifestations multi-scalaires de la crise dans un contexte d'austérité continue. Le thème du mort-vivant relie les idées économiques «mortes » qui sont réanimées par l'économie zombie à la logique de l'absence d'alternative («There Is No Alternative ", ou TINA). Par ailleurs, le monstre zombie permet de connecter, de manière viscérale, les atteintes portées à la santé physique et mentale des personnes, et les valeurs sousjacentes perpétuées par l'austérité. C'est la crise à l'échelle du corps qui se manifeste sous la forme de la macro-économie zombie de l'austérité. Cet article propose de penser l'esthétique de l'austérité comme la frontière problématique entre ce qui est vivant et ce qui est mort - une distinction binaire en termes corporels mais fluctuante en termes politiques et économiques.

\section{INDEX}

Keywords: zombie economy, austerity, aesthetic, neoliberalism, health, mental illness

Mots-clés: économie zombie, austérité, esthétique, néolibéralisme, santé, maladie mentale

\section{AUTHORS}

\section{RUTH CAIN}

Dr. Ruth Cain is Senior Lecturer in Law at the University of Kent. She has published on the law and politics of mental health, family law and literature among other subjects. Her most recent publications are "Shared Care after Separation in the United Kingdom: Limited Data, Limited Practice?" with Tina Haux and Stephen McKay in Family Court Review 55 (4) 2017 and "Responsibilising Recovery: Lone and Low-paid Parents, Universal Credit and the Gendered Contradictions of UK Welfare Reform" in British Politics 11 (4) 2016. She is currently working on a book project about the politics of measurement and tracking techniques for mental health and illness to appear in the Bristol University Press series Quantified Societies and Selves. Contact: r.c.m.cain[at]kent.ac.uk 


\section{JOHNNA MONTGOMERIE}

Dr. Johnna Montgomerie is a Reader in International Political Economy at King's College London. Her research expertise is in political economy, global finance, the household, debt-led growth and austerity. She is convenor of the International Political Economy Group (IPEG) and Council Member of the Progressive Economy Forum (PEF). She has a forthcoming monograph with Polity, Should We Abolish Household Debt?, an edited volume with Routledge, Critical Methods in Political and Cultural Economy, and her most recent article with Daniela Tepe-Belfrage, "Cultures of Debt Resistance," was published in Geoforum (May 2018). Contact: johnna.montgomerie[at]kcl.ac.uk 